\title{
Modelling Perjury: Between Trust and Blame
}

\author{
Izabela Skoczeń ${ }^{1}[$
}

Accepted: 4 January 2021 / Published online: 21 February 2021

(c) The Author(s) 2021

\begin{abstract}
I investigate: (1) to what extent do folk ascriptions of lying differ between casual and courtroom contexts? (2) to what extent does motive (reason) to lie influence ascriptions of trust, mental states, and lying judgments? (3) to what extent are lying judgments consistent with previous ascriptions of communicated content? Following the Supreme Court's Bronston judgment, I expect: (1) averaged lying judgments to be similar in casual and courtroom contexts; (2) motive to lie to influence levels of trust, mental states ascriptions, and patterns of lying judgments; (3) retrospective judgments of lying, after being presented with the state of the world, to be inconsistent with previous judgments of communicated content: participants hold the protagonist responsible for content she did not communicate. I performed a survey experiment on the Qualtrics platform. Participants were recruited through Amazon Mechanical Turk $(\mathrm{N}=630)$. I employed standard Likert scales and forced-choice questions. I found that: (1) average lying judgments are similar in casual and courtroom contexts; (2) motive to lie decreases trust ascription and increases lying judgment; (3) judgments of lying are inconsistent with previous judgments of communicated content: participants hold the protagonist responsible for content they did not communicate (effect size of the difference $d=.69$ ). Perjury ascriptions are inconsistent. The Supreme Court's worries expressed in the Bronston judgment are well founded. This article helps reforming jury instructions in perjury cases.
\end{abstract}

Keywords Perjury · Trust · Indirect answer · Scalar implicature $\cdot$ The Bronston case $\cdot$ Witness cross-examination $\cdot$ Blame

Izabela Skoczeń

izaskoczen@gmail.com

1 Department of Legal Theory, Faculty of Law and Administration and Jagiellonian Centre for Law, Language and Philosophy, Jagiellonian University, Cracow, Poland 


\section{Introduction}

Samuel Bronston, the owner of Samuel Bronston Productions based in New York, made movies in various European countries to lower the movie production costs. As discovered later, he therefore kept bank accounts in 37 different countries. In 1964, after one of the company's big movie productions, The Fall of the Roman Empire, proved a financial catastrophe, Bronston filed for federal bankruptcy protection. During the court proceedings, Bronston was questioned under oath about his offshore bank accounts by a lawyer representing his creditors. The following exchange ensued:

Question. Do you have any bank accounts in Swiss banks, Mr. Bronston?

Answer. No, sir.

Q. Have you ever?

A. The company had an account there for about six months, in Zürich.

Q. Have you any nominees who have bank accounts in Swiss banks?

A. No, sir.

Q. Have you ever?

A. No, sir. [10]

All the answers were literally true. However, the answer "the company had an account there for about six months, in Zürich" suggests that Bronston himself had no bank account in Switzerland, yet it was later discovered that he had one in Geneva. Consequently, following this discovery, federal prosecutors secured a perjury indictment against Mr. Bronston. The court had to answer the question whether Bronston lied.

The jury was instructed to think about Bronston's mental state and find out whether he "fully understood the questions put to him but nevertheless gave false answers knowing the same to be false"1 [10]. After a long discussion, the jury convicted Bronston. The lay jury verdict was clear: Bronston lied.

However, Bronston's lawyers appealed, claiming that he never said anything false, and it was the questioning prosecutor's duty to press Bronston to elaborate on the matter. Since the prosecutor did not ask additional questions and Bronston had no obligation to speak more precisely, Bronston was, in their view, innocent.

\footnotetext{
1 Currently, US law only specifies testimony that the defendant "does not believe to be true." 81

The 1911 UK Perjury statute has a slightly different wording:

If any person lawfully sworn as a witness or as an interpreter in a judicial proceeding wilfully makes a statement material in that proceeding, which he knows [emphasis added] to be false or does not believe to be true, he shall be guilty of perjury,... 80

If any person, in giving any testimony (either orally or in writing) otherwise than on oath, where required to do so by an order under Sect. 2 of the Evidence (Proceedings in Other Jurisdictions) Act 1975, makes a statement:
}

(a) which he knows to be false in a material particular, or.

(b) which is false in a material particular and which he does not believe to be true,

he shall be guilty of an offence... 79

Choice of rules from [35]. 
After appeals, the case reached the Supreme Court, who reversed the jury judgment and upheld the appeal: Bronston did not lie. The Supreme Court feared that in such courtroom cases, folk intuitions about lying would not be robust, as well as that they would not be consistent, and therefore would be easily manipulable [10]. This decision drew massive criticism. The Supreme Court was accused of creating a loophole in the perjury statutes that would permit witnesses to lie in court without consequences. The Bronston case influenced thousands of further perjury trials. This case was also used later in the perjury proceedings involving President Bill Clinton, which raised a huge public controversy [18].2

So, who is right? Are folk intuitions about perjury robust? Or is the Supreme Court (SC) correct that this is shaky ground where one should proceed with extreme caution? This study recruited survey participants and performed a quantitative analysis of their responses to the question.

\section{The Supreme Court's Two Major Worries}

The SC had two major worries. The first one concerned context type. The SC feared that lying means something different in casual, everyday contexts than in a courtroom setting. The SC stated its opinion:

There is, indeed, an implication in the answer to the second question that there was never a personal bank account; in casual conversation this interpretation might reasonably be drawn. But we are not dealing with casual conversation and the statute does not make it a criminal act for a witness to willfully state any material matter that implies any material matter that he does not believe to be true [10].

Thus, the SC suggested here that there is a qualitative difference in what constitutes a lie in a casual and a courtroom context and juries do not see the difference [34, 68].

The second major worry of the SC is that there is a class of court proceedings such as bankruptcy proceedings that is special because the witness has a motive (reason) to mislead:

\footnotetext{
${ }^{2}$ Interestingly, the legal discussion on the Bronston case is mirrored by a discussion in philosophy of language where Jorg Meibauer argues that indirect answers such as Bronston's are lies [48, 49], while Jennifer Saul argues that such indirect answers should not be taken as lies but as merely misleading statements (even if the folk treats them as lies) (cf. also $[1,14,65]$ ). This claim is also advocated by Solan and Tiersma [ 67], Tiersma [75, 76] as the 'literal truth defense': lying requires (knowingly) false statements, and as the Supreme Court noted, Bronston's statements were not false.

Others argue that this depends whether the false inference from the answer would arise in most contexts or only in a special, particular context [19, 21, 34, 50, 68]. Moreover, there is a considerable literature which tests these claims empirically but does so outside of the courtroom context (cf. for instance [77]), which has been criticized by Wiegmann et al. [85]. Recent empirical findings point out to the crucial role of the notion of commitment (cf. $[58,86])$.
} 
It should come as no surprise that a participant in a bankruptcy proceeding may have something to conceal and consciously tries to do so, or that a debtor may be embarrassed at his plight and yield information reluctantly [10].

The SC feared that this motive might generate low trust levels toward the speaker's words, which might in turn generate inconsistencies in jurors' perjury judgments: the speaker might be held responsible for content she did not communicate. This issue is especially pressing as there is a maxim in legal interpretation that states that motive is irrelevant to responsibility if one is not sure whether the accused really acted upon the motive (cf., for instance, [53, 59]). Moreover, in continental legal systems, for instance in France, considering motives is prohibited when evaluating whether the agent acted with general intent. In other words, motives are irrelevant for ascriptions of general intent, except when the code explicitly states that a concrete motive is needed [5, 7, 20, 57]. However, empirical studies depict that when experiment participants ascribe intention, they consider 'the agent's reasons or motives for acting when computing blame' (45, cf. also [44, 51], see also [39]).

\section{Indirect Answers}

When asked whether he had ever any bank accounts in Swiss banks, Bronston replied, "The company had an account there for about six months, in Zürich." The answer suggests that Bronston himself did not have an account in a Swiss bank. In the philosophy of language, this suggestion is called an implicature. In fact, in everyday speech, it is quite common to convey more than just the the meanings of the words we utter. If A asks B in the morning, "Are you hungry?" and B replies, "I have just had breakfast," then B implies that she is not hungry even though she does not explicitly state that. Paul Grice labeled such indirect answers "conversational implicatures". He claimed that we can convey implicatures because we all share a common communicative assumption named the "cooperative principle": "Make your contribution such as is required, at the stage at which it occurs, by the accepted purpose or direction of the talk exchange in which you are engaged" [28].

According to Grice, this principle can be unpacked into four conversational maxims:

1. Quality: (1) do not say what you believe to be false; (2) do not say that for which you lack adequate evidence.

2. Quantity: (1) make your contribution as informative as is required (for the current purposes of the exchange); (2) do not make your contribution more informative than is required.

3. Relation: be relevant.

4. Manner: be perspicuous; (1) avoid obscurity of expression; (2) avoid ambiguity; (3) be brief (avoid unnecessary prolixity); (4) be orderly [28].

The above framework laid the groundwork for modern theories in the philosophy of language, which refined it, yet kept it (with various modifications) as a good 
basis for describing everyday linguistic communication. However, when language exchanges in the legal realm are at stake, scholars have pointed out that this framework leads to different inferences than in everyday speech because the goal of the exchange is different. This is because in such exchanges, the main goal is rarely to just transmit information one has. Rather, the goal is to win the case, and this might involve a highly selective sharing of information that maximizes the chances of winning. This results in either different patterns of implicature ascriptions or in refraining from implicature inference because it is uncertain what the maxim of quantity (be as informative as required for the puprposes of the exchange) requires [23, 43, 46, 47, 55, 56, 66, 69, 78]. Take the following example provided by Marmor:

Consider, for example, a stipulation in some commercial contract saying " $\mathrm{X}$ will not issue A without Y's proof of B." In an ordinary conversation, a hearer would have inferred that proof of $\mathrm{B}$ is the only condition for $\mathrm{X}$ to issue $\mathrm{A}$; otherwise, the speaker would have flouted the maxim of quantity (do not say too little). But in the context of commercial negotiations, this would be a very insecure inference. $\mathrm{X}$ might want to be able to claim that stating one condition does not necessarily preclude others, and $Y$ might be expected to know this, to some extent, and to know that this might be what $X$ presumes in the conversational context [emphasis added] [47].

In the above example, the sentence " $\mathrm{X}$ will not issue A without $\mathrm{Y}$ 's proof of B" does not automatically give rise to the implicature that $\mathrm{Y}^{\prime}$ 's proof of $\mathrm{B}$ is the only condition for issuing A, because we are in a special context. In the context of commercial negotiations, one is expected to be cautious because one knows that the interlocutor might want to leave matters open, and thus it is safer not to infer that Y's proof of B is the only condition for issuing A. It is especially not clear what the maxim of quantity requires, and the negotiating parties know that. ${ }^{3}$

The SC's worry about Bronston's utterance is analogous: in the courtroom context, Bronston's answer should not automatically give rise to the inference that he himself did not have a bank account in Switzerland, because a hearer is also expected to be cautious, though for a slightly different reason. As the SC phrased it, "A participant in a bankruptcy proceeding may have something to conceal," [10] and thus she is to be distrusted. Thus, an analysis analogous to Marmor's example leads to the claim that hearers would refrain from implicature inference in the courtroom. There is, however, a competing analysis of what happens in a distrust context like the one described. As Claudia Bianchi argues:

\footnotetext{
${ }_{3}^{3}$ To give another example, in an every-day context, when you hear 'If you mow the lawn I'll give you $\$ 5$ ' you infer that if you don't mow the lawn I won't give you the money. This is labeled 'conditional perfection', the inference from "If $\mathrm{p}$ then q" to "Only if $\mathrm{p}$, q" (or, equivalently, to "If not-p then notq"), which can be accounted for as an implicature. Yet there can be contexts in which this inference is blocked (cf. [24, 82, 32]).
} 
In a strategy of Naïve Optimism, ${ }^{4}$ following the assumption that Bronston is both benevolent (obeying Grice's Maxims, and in particular the first Maxim of Quantity) and competent, his utterance

(8) The company had an account there for about 6 months, in Zurich will be taken to imply

(9) I have never had a personal bank account in a Swiss bank.

In more sophisticated strategies, however, the addressee shouldn't stop at the first relevant enough interpretation that comes to mind ((9)). A Cautious Optimist should stop at the first interpretation that the speaker might have thought would be relevant enough to the interpreter. Bronston could be benevolent but not competent, and think that, say, only the Company bank accounts are relevant in a bankruptcy hearing: in this case (8), not (9), would be the most relevant interpretation that Bronston might have thought would be relevant enough to the Court. Nonetheless, the adequate strategy in the Bronston case is Sophisticated Understanding: the examining lawyer should have dropped the assumption of benevolence and interpreted Bronston as merely intending to seem benevolent and informative, and avoid lying. The lawyer should have identified (9) not as the truly relevant interpretation, but only as the interpretation Bronston might have thought would seem relevant enough to the Court ([8], p. 196).

Bianchi argues that in the Bronston case, a hearer should infer the implicature yet disbelieve the speaker. However, do people descriptively speaking behave this way when processing utterances in the courtroom? Or rather, do they refrain from implicature inference as Marmor suggests? In this empirical study, I will investigate which claim, Marmor's or Bianchi's, is supported by psychological data.

To reiterate, Marmor claims that: in a distrust context like the Bronston case, participants do not know whether the speaker follows the maxim of quantity. As a result, they refrain from implicature inference. For example, in the Bronston case, they take Bronston as communicating that perhaps he had a personal bank account in a Swiss bank. In other words, participants understand that Bronston's utterance about the company does not preclude that he himself had an account.

By contrast, Bianchi claims that participants' beliefs about what is communicated and about the state of the world diverge. Consequently, participants understand the implicature yet disbelieve the speaker. For example, in the Bronston case, they take Bronston as communicating that he himself did not have an account in a Swiss bank.

\footnotetext{
${ }^{4}$ This is a strategy introduced by D. Sperber: "Suppose John is very trusting indeed and takes for granted that Carol is behaving both benevolently and competently. Then John can take for granted two further things: that the information Carol wants to convey to him is information worth his attention, and that the means she is using to convey that information should make it as easy as possible for him to retrieve it" [71]. The idea of different degrees of relevance of the speech depending on the strategy adopted was introduced in the so-called Relevance Theory [72].
} 
However, they do not believe in what Bronston communicates; they think that the state of the world is the opposite: Bronston had an account in a Swiss bank.

The first step of this empirical study was to check which account, Marmor's or Bianchi's, is closer to the psychological reality of processing utterances in a courtroom. The second step, dependent on the first, was to check whether the SC's worry about the inconsistency of folk intuitions about lying is well founded. The second step consisted of providing participants with explicit information that the putative implicature was false. For example, it provided participants with the information that Bronston indeed had a personal bank account in a Swiss bank and asked participants whether Bronston had lied.

The conclusion drawn from the results collected in the second experimental step is dependent on the results of the first experimental step because if it turned out that Bianchi is correct (participants first infer the implicature and next when the implicature turns out false judge it as a lie ${ }^{5}$ ), then the SC's worry is unfounded: participants will consistently assess false communicated content as a lie. To take the Bronston example, they will first assess that Bronston communicated that he himself did not have an account, and second, since it turns out not to be true, participants will assess this as a lie.

By contrast, if it turns out that Marmor is correct (participants first refrain from implicature inference and next when the putative implicature turns out false judge it as a lie), then the SC's worry is very well founded: participants will hold the protagonist responsible for something she did not communicate, which is unfair. For example, participants will assess that Bronston communicated that he does not preclude he had an account, and later, when it turns out that Bronston indeed had an account, participants inconsistently assess the initial Bronston's utterance as a lie.

\section{Scalar Implicatures}

There are many types of implicatures [40], but in the paper, I focus entirely on scalar implicatures (the Bronston case can be considered a variety of those, see below), which have been widely debated in the literature. Scalar implicatures arise in most contexts where the words giving rise to them are employed [27, 36, 41]. There is a heated debate on their exact nature [25, 64], and many claim that certain scalar implicatures are even within the dictionary meaning of the words that give rise to the inference of these scalar implicatures [11, 41], similarly claiming that scalar inferences can be explained with a semantic operator "only": [12, 13, 22],for a

\footnotetext{
${ }^{5}$ One note of caution for Bianchi's account: in my experimental design I employ a major simplification, namely I do not ask separate questions on lying and misleading. I do it on the assumption that participants thinking that the assessed false implicature is merely misleading will not judge it as a lie, in accordance with the findings of Weissman and Terkourafi [84]. When this is the case, then no problem for perjury arises since a jury so thinking would not convict the speaker of perjury, thinking that the false implicature is merely misleading rather than a lie and the speaker believed her statement to be true. Analogously, on Marmor's account, participants who do not infer the implicature at all cannot consider it misleading, since they have not inferred it in the first place. Thus, in such case no perjury conviction ensues.
} 
different view cf. $[4,25,31,54,60,63,70]$. In the experiment, when testing whether people refrain from implicature inference in a distrust context, I employed scalar implicatures.

So, what is a scalar implicature? When people hear that the company had an account in Zurich, they infer that the speaker did not, otherwise he would have said he had one. Analogously, when people hear that some of the invoices are unpaid, they infer that not all of them have been paid and there is at least one uncovered invoice. They do so because had the speaker wanted to convey that all the invoices are unpaid, she would have used the word "all" rather than "some." The traditional account calls this reasoning a "scale" consisting of two words: "some" and "all." Very roughly, if a speaker uses a word that is lower on the scale (for example, "some"), then the speaker communicates the negation of the word higher on the scale (for example, "all”) [33].

Analogously, in the Bronston case, one could conceive of the answer as a scale constituted of '[only] the company has an account' and 'the speaker has an account'. If Bronston said that the company had an account, then he implicated the negation of 'the speaker has an account'. However, the Bronston example is more complex than the 'some' example, since the scale inferences in the Bronston case do not only involve the maxim of quantity (say as much as you can), but also the maxim of relation (be relevant in answering the posed question, which concerned the speaker's bank accounts) (cf. [67]). In order to keep the experimental setting as simple as possible, the present studies will focus on the less complex 'some' example, however, testing more complex cases with a question under discussion remain an avenue for future inquiry.

The above described scale explanation of scalar implicatures can be debated, but for our purposes it suffices to say that the label "scalar" for this type of implicatures comes from the idea that perhaps such scales explain the processing of the described implicatures. The "not all" inference from 'some' can be debated as an implicature. Consider the sentence uttered in the context of a company undergoing bankruptcy proceedings:

(1) If some of the invoices are unpaid, then the accountant will be fired.

Here the inference is that if all the invoices are unpaid, then the accountant will naturally also be fired. This is a 'downward entailing context' given the reversal of informative strength and thus the reversal of the scale: the replacement of "some" by "all" yields a weaker rather than stronger statement [41]. Thus, the meaning of "some" is "some and maybe all" instead of "some but not all."

To test the SC's claims presented in the Bronston case, I needed an experimental setting in a courtroom context where I was able to check whether participants who have a decreased trust toward the speaker, when presented with the utterance that can give rise to scalar implicature, e.g. "some of the invoices are unpaid", indeed treat "some" as communicating "at least some and maybe all the invoices are unpaid." If this is the case, then the next step was to tell participants that it turned out that all the invoices were indeed unpaid and check whether they then considered 
Table 1 The structure of Marmor's and Bianchi's predictions concerning the processing of an utterance containing the word "some" as well as the Supreme Court's worry of judgment inconsistency

\begin{tabular}{|c|c|c|c|c|c|}
\hline $\begin{array}{l}\text { Order of } \\
\text { judgment }\end{array}$ & & $\begin{array}{l}\text { Ascribed } \\
\text { probability that } \\
\text { all objects have } \\
\text { the property }\end{array}$ & $\begin{array}{c}\text { Ascribed } \\
\text { communicated } \\
\text { content }\end{array}$ & $\begin{array}{l}\text { Discovered state } \\
\text { of the world }\end{array}$ & Lying judgment \\
\hline \multirow{2}{*}{ Consistent } & $\begin{array}{l}\text { Bianchi's } \\
\text { prediction }\end{array}$ & High & $\begin{array}{c}\text { Some but } \\
\text { not all }\end{array}$ & All & Lie \\
\hline & $\begin{array}{l}\text { Marmor's } \\
\text { prediction }\end{array}$ & High & Maybe all & all & Not a lie \\
\hline
\end{tabular}

Inconsistent

(biased)

High $\Rightarrow$ Maybe al

all

Lie

the utterance a lie. If they did consider the utterance a lie, just as in the Bronston case, then the SC's conclusion that folk intuitions about lies in courtrooms are inconsistent is correct: participants hold the speaker responsible for something she did not communicate, namely that there is a covered invoice (not all the invoices are unpaid), which would be unfair (Table 1).

\section{Intent to Mislead is Irrelevant to Responsibility for Perjury}

Before proceeding further, one more crucial terminological clarification. In the philosophy of language literature, following a long tradition, Jennifer Saul argues that there is a distinction between intending to deceive and intending to mislead. Intention to deceive is the case when, very roughly, the speaker utters a statement she believes to be false. Such behavior is, according to Saul, labeled lying. By contrast, if the speaker utters a true statement which yields a false implicature (or an implicature the speaker believes to be false), then the speaker is merely misleading, yet cannot automatically be labeled a liar. Saul extensively argues that misleading is not morally better than lying, with however one exception: the courtroom context. The reason for this exception is that in the courtroom, if a witness utters a false statement, then the questioning lawyer has no duty to clarify it. By contrast, if the witness utters a statement with a suspicious implicature, then it is the duty of the lawyer to clarify it and so the burden of responsibility is not on the witness:

In a courtroom, a witness is required to answer the questions that a lawyer puts to them. If either of the lawyers in an adversarial system is not satisfied with their answers, it is the lawyer's job to pursue the questions further. The lawyers are trained professionals, well versed in these matters. It is very much the lawyer's job to notice that a witness is not answering the question asked, and to force them to answer the right question. As a result, the lawyer question- 
ing Bronston had a responsibility to press Bronston further on his misleading statement. [65]

In the remaining parts of the paper, I will not employ Saul's distinction in the sense that I will write of intent to mislead as leading to potential lies. I do so because, just as the SC, I suspect that lay participants will not make this crucial difference in the courtroom context, which could potentially lead to unfair convicitons of perjury.

Moreoever, if the SC's above described predictions turn out to be accurate and participants indeed hold the speaker responsible for something she did not communicate, then there remains the question as to the cause of such inconsistent judgment. Perhaps due to the fact that the state of the world turned out contrary to the not inferred implicature, participants retrospectively blamed the protagonist for trying to fool them and ascribed to the protagonist an intent to mislead them with the utterance? If this is the case, then, as the SC points out, it is precisely what a jury should not do:

It is no answer to say that here the jury found that petitioner intended to mislead his examiner. A jury should not be permitted to engage in conjecture whether an unresponsive answer, true and complete on its face, was intended to mislead or divert the examiner; the state of mind of the witness is relevant only to the extent that it bears on whether "he does not believe [his answer] to be true." To hold otherwise would be to inject a new and confusing element into the adversary testimonial system we know. Witnesses would be unsure of the extent of their responsibility for the misunderstandings and inadequacies of examiners and might well fear having that responsibility tested by a jury under the vague rubric of "intent to mislead" or "perjury by implication" [10].

In other words, according to the SC, it is not relevant to the offense of perjury whether the witness had a desire to mislead for which the witness is to be blamed. The only question that matters is whether the witness did not believe her answer to be true. Yet Bronston believed that his utterance was true. Note that the structure of the offense of perjury is different than for example the distinction between voluntary and involuntary manslaughter, in which distinction the ascription of intent (and most probably desire) is clearly decisive.

In the experiment I will measure whether participants indeed blame the speaker for her words. To reiterate, if I find that participants are guided by their judgments of blame in their determinations of perjury, then participants will be interpolating a criterion which is not actually part of either the definition of perjury or the folk theory of lying (which includes an intention to deceive but not a judgment of blame per se). Consequently, if the blame criterion proves robust, then it might be the case that judgments of lying are biased by blame ascriptions. 


\section{The Hypotheses and Experimental Design}

\subsection{The Ex Ante Probability}

In order to distinguish an implicature from a prior belief that it is unlikely that all objects have the property [26], I first presented participants with the following information:

Invoices for more than a 1,000,000 USD found in the documentation of companies in bankruptcy proceedings are almost always unpaid. A paid invoice of this kind is an extreme rarity. On the table, there are five invoices for more than 1,000,000 USD from a company undergoing bankruptcy proceedings.

Next, I asked a question on the probability of all objects having the property before being presented with an utterance, to make sure participants assessed it as high (above 50\%). I measured probability on a 0-100 slider scale, as it is natural to speak of probability in terms of percentages [37]:

On a scale from 0 (completely unlikely) to 100 (certain) how likely is it that all of the invoices are unpaid?

I supposed that the answers to this question would be over $50 \%$ i.e. participants would understand that there is a high probability that all of the invoices are unpaid.

\subsection{The Three Context Types}

Recall that in the Bronston judgment, the SC had two major worries. The first worry was that juries do not make the distinction between casual and courtroom contexts in their lying judgments. The second worry was that the existence of a motive to lie generates inconsistencies in the jury's lying judgments.

In order to verify whether the two worries are well-founded, I designed three context types: (1) a neutral context, (2) a courtroom context without an explicitly stated motive to lie, and (3) a courtroom context with an explicitly stated motive to lie. I employed a between-subjects design and first split participants into three groups. Each participant was presented with only one of the following three context descriptions containing the exact same utterance (the content in brackets was not presented to participants):

[neutral] Imagine a conversation at the company headquarters. The main accountant of the company says in reply to the boss' question during the conversation at the company's headquarters: 'Some of the invoices are unpaid.'

[courtroom no explicit motive] Imagine a courtroom hearing. The main accountant of the company says in reply to the judge's question during the courtroom hearing: 'Some of the invoices are unpaid.'

[courtroom with explicit motive] Imagine a courtroom hearing. The main accountant of the company undergoing the bankruptcy proceedings has interest in claiming that there is a paid invoice because this increases his chances of 
receiving substantial remuneration before the company is declared bankrupt. The main accountant of the company says in reply to the judge's question during the courtroom hearing: 'Some of the invoices are unpaid.

\subsection{The Ex Post Probability}

Next, I asked a question on the ex post (after being presented with utterance) probability that all the objects had the relevant property:

Now, on a scale from 0 (completely unlikely) to 100 (certain) how likely is it that all of the invoices are unpaid?

In a paired samples $t$ test, I compared the answers to this question with the answers to the question on the ex ante (before being presented with utterance) probability that all objects had the property by the same participants (within-subjects). If there was a significant difference between the answers on ex ante and ex post probability of all objects having the property, then participants understood and believed the speaker that not all the objects had the property and updated their beliefs about the world accordingly. Following the SC's reasoning (Sect. 2) I predicted most participants would answer in this way because this is the standard inference in everyday communication contexts and, as pointed out in the introduction, the SC claims that there is no major difference between inferences in such everyday casual and courtroom contexts.

\subsection{The Communicated Content}

However, if there is no significant difference between assessment of ex ante and ex post probability of all objects having the property, then following the two alternative interpretations, by Marmor and Bianchi (Sect. 3), participants have either understood and believed the speaker as claiming that perhaps even all the objects had the property, or participants have disbelieved the speaker, whom they understood to be precluding that all objects had the property. In order to disentangle these two possibilities, I added an additional, forced-choice question on communicated content (Fig. 1):

When uttering "Some of the invoices are unpaid" the main accountant wanted to communicate that: (a) only some but not all of the invoices are unpaid. (b) at least some and maybe all of the invoices are unpaid. ${ }^{6}$

I randomized the order of answer presentation. I assumed that those who assessed ex ante and ex post probability similarly (no significant difference) and chose the answer "At least some and maybe all of the objects have the property" to the question on communicated content understood and believed the speaker as claiming that

\footnotetext{
${ }^{6}$ Note that if I asked simply what the speaker communicated, then the number of 'some and maybe all' answers would be even higher.
} 
perhaps even all the objects had the property. This means that these participants refrained from implicature inference, which is Marmor's prediction described in Sect. 3 (cf. [17, 47, 84, 87]).

By contrast, those who assessed ex ante and ex post probability similarly (no significant difference) and chose the answer "Some but not all of the objects have the property" disbelieved the speaker, whom they understood to be precluding that all objects had the property. This means that these participants inferred the implicature that not all the objects had the property, but since they disbelieved the speaker, their beliefs about what was communicated and about the state of the world were divergent. This is Bianchi's prediction described in Sect. 3 [8].

\subsection{Trust}

Following the SC's ruling as well as Marmor and Bianchi's diagnoses of the discussed courtroom contexts, I suggest that in both putative cases where there will not be a significant difference between the ex ante and ex post rating (the first being a lack of implicature inference and the second a disbelief in the speaker's communicated content), participants distrust the speaker's presented utterance. In order to investigate whether this is the case, I asked a question on trust assessment on a standard 1-7 Likert scale:

To what extent is the main accountant's utterance trustworthy? $(1=$ not at all trustworthy; 7 = completely trustworthy)

Based on the SC's second worry described in Sect. 2, I suggested that the overall trust assessment would be significantly lower in the courtroom contexts with the presence of an explicitly stated motive to lie (this was checked in an independent samples $t$ test between context types). I also suggested that participants who answered the trust question over the mid-point 4 , which means that they trusted the speaker's words, would provide significantly different answers on ex ante and ex post probability assessment of all objects having the property. Moreover, I suggested that these participants would choose the answers "Some but not all of the objects have the property" to the question on communicated content most of the time. I based this prediction on the SC claim that folk intuitions about casual and the courtroom contexts do not differ if there is no difference in trust levels.

Since the question on communicated content was a forced-choice question, I measured the frequency of answers assessing communicated content with a nonparametric chi-square test. I compared whether there was a significant difference in the number of the two possible answers in the question on communicated content. I predicted that overall, there would be a significant difference: the number of answers "some but not all" would be significantly higher than the number of answers "at least some and maybe all." I again based this prediction on the SC's claim that folk intuitions do not differ much in casual and the courtroom contexts if there is no difference in (high) trust levels. 
By contrast, I suggested that participants who answered the trust question below the mid-point 4, which means that they distrusted the speaker's utterance, would provide similar answers on the ex ante and ex post questions on probability of all objects having the property. Moreover, they would be more likely to choose the answer "At least some and maybe all of the objects have the property" to the question on communicated content than the participants that trusted the speaker's utterance. Since this is a forced-choice question, I measured that with a non-parametric chi-square test. I compared whether there was a significant difference in the number of the two possible answers in the question on communicated content. I predicted that there would be no significant difference: the number of participants who chose the "some but not all" interpretation would be similar to the number of participants who chose the "at least some and maybe all" interpretation following Marmor's interpretation described in Sect. 3.

\subsection{Knowledge}

Next, before proceeding to test the participants' assessment of lying, I needed to restrict participants' answers to those that would be legally relevant for perjury assessments. The jury instruction for perjury is that it has to be assessed whether the defendant "gave false answers knowing [emphasis added] the same to be false" $[10] .^{7}$

Thus, I needed an additional question on knowledge assessment so as to later restrict the analysis of lying assessment to only those participants that judged the protagonist as knowing how many objects had the relevant property:

To what extent do you agree with the following statement: "the main accountant knows how many invoices are unpaid'? $(1=$ completely disagree; $7=$ completely agree).

\subsection{Lying}

Next, I presented participants with either the information:

It turns out that all of the invoices are unpaid.

Or with the information:

\footnotetext{
${ }^{7}$ Note that, the 1911 UK Perjury Act and its 1975 revision state that:

If any person, in giving any testimony (either orally or in writing) otherwise than on oath, where required to do so by an order under Sect. 2 of the Evidence (Proceedings in Other Jurisdictions) Act 1975, makes a statement-

(a) which he knows to be false in a material particular, or

(b) which is false in a material particular and which he does not believe to be true,

he shall be guilty of an offence....

Given possibility (b), in the UK the knowledge criterion is more relaxed: a belief that the statement is not true is sufficient. However, the present paper focuses on the criteria enlisted in the Bronston case, in which, as indicated in the quotation, the knowledge criterion is important.
} 
It turns out that not all of the invoices are unpaid. ${ }^{8}$

I next asked participants a question on lying assessment:

To what extent do you agree with the following statement: 'the main accountant's utterance was a lie'? $(1=$ completely disagree; $7=$ completely agree $)$

Technically speaking the notion of lying is not part of determining whether perjury occurred. However, the notion of lying is a natural language analogue for expressing responsibility for false statements. Thus, lay juries might have a tendency to follow closely their lying intuitions when adjudicating perjury. Consequently, a question on lying is in place.

I restricted the main analysis to datasets of participants presented with the information "It turns out that all of the invoices are unpaid." I suggested that on average, those who chose the answer "At least some and maybe all objects have the property" in the question on communicated content would judge the utterance as not being a lie, while those who chose the answer "Some but not all objects have the relevant property" in the question on communicated content would assess the utterance as a lie. This follows from the assumption that a speaker is held responsible only for content that she communicated. If the state of the world turns out contrary to communicated content can a speaker be assessed as a liar.

Moreover, in line with previous theoretical and experimental literature (cf. [1, 17, $65,83,84]$ ), there is always a fraction of the population, which judges a false implicature not as a lie but as merely a misleading statement. However, this fraction of the population is less problematic for the present studies, as those who do not judge a false implicature as a lie, would most probably not judge the false implicature as perjury, though this remains an avenue for future studies. One could however raise a reverse worry: since there is no separate question on misleading being asked, a fraction of participants might be conflating misleading with lying. These participants answer the lying question in the affirmative, even if they do not think the evaluated utterance was a lie, or they think a false implicature was less of a lie than a false statement. I acknowledge this worry and leave it as an avenue for future studies.

However, following the SC's second worry, I suggested that patterns of lie ascritpions would change if I considered only the answers of those who did not trust the speaker's utterance (answers on the trust question below the mid-point 4) and chose the answer "at least some and maybe all of the objects have the relevant property" in the question on communicated content. Following the SC's worry combined with

\footnotetext{
${ }^{8}$ Note that I first asked the question on knowledge and only later provided participants with the state of the world. This order, however, was not present in the Bronston case and other perjury cases: the jury already knew the state of the world when assessing the knowledge state of the defendant (if the state of the world conformed to the putative implicature content, then there would not even be a perjury case). The SC is right to worry that this is extremely shaky ground: the outcome or hindsight bias is well established in psychology, and it is highly probable that the fact that a jury is presented with a state of the world contrary to the putative implicature might drive them to ascribe more knowledge to the defendant than they would ascribe if they did not know the state of the world in advance [6,37]. Consequently, this could drive the jury to ascribe higher lying (or perjury) scores. The SC's worries about lay intuitions on lying are far from being unfounded.
} 
Marmor's prediction described in Sect. 3, I suggested that these participants would judge the utterance as a lie despite the fact that they did not infer the implicature: they would hold the speaker responsible for something she did not communicate. I measured this by checking with a one-sample $t$ test whether the average answer on the lying question was different from the mid-point 4 . I also checked whether participants who gave all the same answers, except for the fact of being presented with the opposite information that "It turns out that not all of the invoices are unpaid," did not judge the utterance as a lie.

If this turns out as predicted, then there arises the question as to the cause of this inconsistency: why hold someone responsible for something she did not communicate? Is it merely because the state of the world turned contrary to the not inferred implicature?

I suggest here that even if these participants rated the utterance as communicating "At least some and maybe all objects have the property," they thought that since it turned out that all the objects had the property, the speaker wanted to fool them and make them think that not all objects had the property: the utterance was a trap. In other words, since they judged the speaker as knowledgeable and did not trust the speaker, they retrospectively ascribed to the speaker a desire to mislead them.

\subsection{Blame}

If I am correct that participants ascribe an intent to mislead to the speaker, then participants must ascribe a high level of blame to the speaker for uttering the sentence "Some of the objects have the property." Consequently, to check whether this is the case, I asked an additional question about blame:

To what extent is the main accountant blameworthy, if at all, for uttering 'some of the invoices are unpaid'? $(1=$ not at all blameworthy; $7=$ extremely blameworthy)

I predicted that levels of blame ascribed would be equally high for those participants that judged the speaker's utterance as trustworthy and communicating that not all the objects had the property (because the speaker broke their trust) as well as for those participants that judged the speaker's utterance as unworthy of trust and communicating that maybe all objects had the property. This is because after discovering the state of the world, participants retrospectively think that the speaker wanted to fool them $[2,6,52]$.

\subsection{Punishment}

The SC is correct that the inference of an intent to mislead is an extremely shaky inference: we are never $100 \%$ sure that someone indeed knew and wanted to mislead-perhaps the speaker's utterance was just unintentionally misleading; perhaps the defendant was not sure how many invoices were unpaid; perhaps the defendant was waiting for the questioning lawyer to inquire further. In the SC's own words: 
Under the pressures and tensions of interrogation, it is not uncommon for the most earnest witnesses to give answers that are not entirely responsive. Sometimes the witness does not understand the question or may in an excess of caution or apprehension read too much or too little into it [10].

Consequently, I asked a question on punishment to check whether participants wanted to punish the speaker despite an uncertainty as to the speaker's mental state:

How much punishment, if any, does the main accountant deserve for uttering "some of the invoices are unpaid"? $(1=$ no punishment at all; $7=$ severe punishment)

I suggested that punishment levels would follow blame levels and that, following the SC's worry, participants would be prone to punish the speaker for her utterance (rating significantly above the mid-point 4). I suggested that this pattern would hold both for those participants that judged the speaker's utterance as trustworthy and communicating that not all the objects had the property (because the speaker broke their trust and deserves punishment) as well as for those participants that judged the speaker's utterance as distrustful and communicating that maybe all objects had the property (because the speaker wanted to fool them and deserves punishment) $[16,62]$.

To sum up, considerations of punishment attributions are external to questions of lying or perjury: they are neither part of the legal responsibility criteria for perjury nor part of the folk theory of lying. However, they can be central to issues such as betrayal of trust and/or of moral reprehensiveness. Consequently, I will investigate the impact of punishment attributions in relation to other tested dependent variables.

The survey ended with a comprehension control question and a demographic questionnaire. The overall experiment structure is presented in Table 2.

\section{Experiment}

\subsection{Participants}

The online Amazon Mechanical Turk platform was used to recruit 630 participants to complete the pre-registered ${ }^{9}$ survey for a small payment $(0.25$ USD). The number of participants was determined by a predictive power analysis carried out with the G-power software. With an effect size of Cohen's $d=0.50, \alpha=0.05$, and power $=0.95$, an a priori power analysis recommends 105 participants per cell for an independent samples $t$ test (two-tailed). I multiplied this value by 6 as there were 6 conditions.

I filtered out participants who (1) were not native speakers of the English language, (2) did not pass the attention check, (3) took less than one minute to complete

\footnotetext{
${ }^{9}$ Link to preregistration: https://aspredicted.org/blind.php?x=ys5us4. Link to repository: https://osf.io/ h7fvd/?view_only=46342fd914ca408b98e91eaee94ffeaf.
} 
Table 2 Order of questions in the overall experiment structure

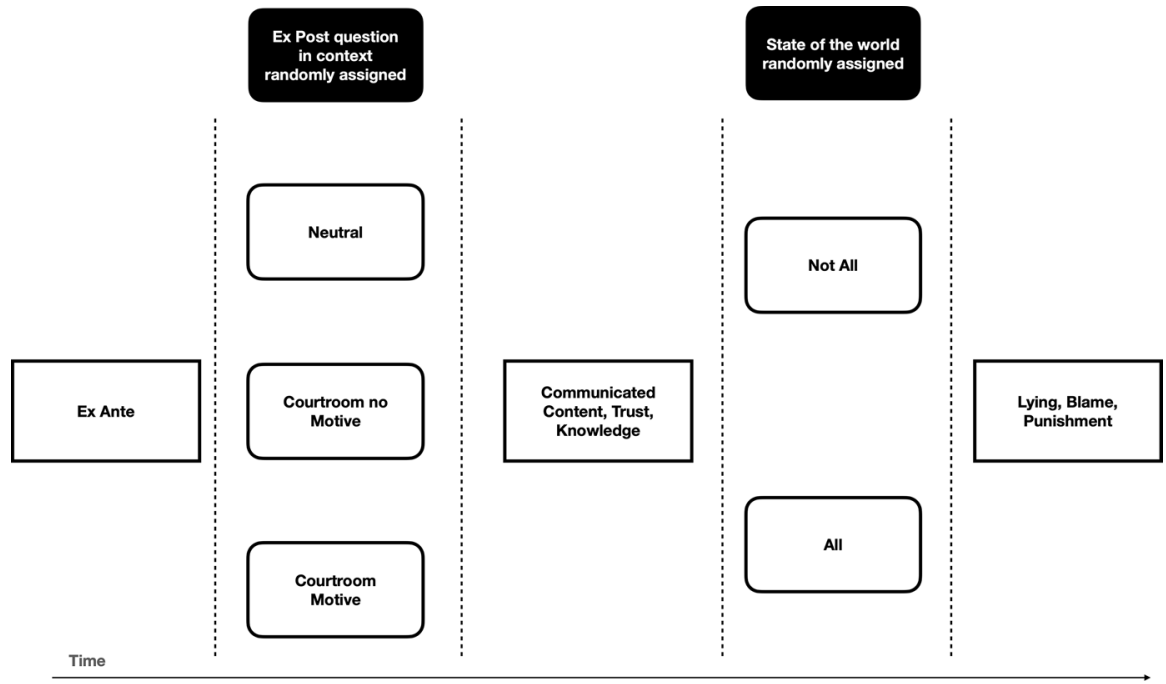

the entire survey, or (4) did not answer the comprehension control question at the end of the survey correctly. After filtering, 489 participants remained (50\% female, mean age 40 years, $\mathrm{SD}=13$ years, range $19-84$ years).

\subsection{Methods and Materials}

The experiment was between-subjects with six conditions: three context type (neutral vs. courtroom without a motive to lie vs. courtroom with a motive to lie) times two state of the world (all vs. not all objects having the relevant property).

After passing the attention check, all participants were presented with the following vignette:

Invoices for more than a 1,000,000 USD found in the documentation of companies in bankruptcy proceedings are almost always unpaid. A paid invoice of this kind is an extreme rarity. On the table, there are five invoices for more than $1,000,000$ USD from a company undergoing bankruptcy proceedings.

Next each participant had to answer a question on ex ante (before being presented with the utterance) probability of all objects having the relevant property on a slider scale ranging from 0 to 100 (as probabilities are naturally measured in terms of percentage):

On a scale from 0 (completely unlikely) to 100 (certain) how likely is it that all of the invoices are unpaid?

Thereafter, participants were presented with the exact same utterance but were split into three groups. The first group was presented with a scenario from a neutral, non-courtroom context, while the second group saw a scenario from a courtroom 
context. The third group was presented with the exact same courtroom context as the second group but with an addition of a motive (reason) to lie (for ease of presentation, this context type will be labeled "motive" further in the paper). For the neutral context, the vignette read:

Imagine a conversation at the company headquarters. The main accountant of the company says in reply to the boss' question during the conversation at the company's headquarters: 'Some of the invoices are unpaid.'

For the courtroom context without explicit motive, an only slightly altered vignette was presented:

Imagine a courtroom hearing. The main accountant of the company says in reply to the judge's question during the courtroom hearing: 'Some of the invoices are unpaid.'

Finally, for the "courtroom context with motive" group, the vignette read:

Imagine a courtroom hearing. The main accountant of the company undergoing the bankruptcy proceedings has interest in claiming that there is a paid invoice because this increases his chances of receiving substantial remuneration before the company is declared bankrupt. The main accountant of the company says in reply to the judge's question during the courtroom hearing: 'Some of the invoices are unpaid.'

Next, all three groups were asked an identical set of questions. First, each participant answered a question on the ex post probability of all objects having the relevant property on a slider scale $0-100$ :

Now, on a scale from 0 (completely unlikely) to 100 (certain) how likely is it that all of the invoices are unpaid?

After answering the probability question, participants were asked a forced-choice question on the content communicated by the utterance:

When uttering "Some of the invoices are unpaid" the main accountant wanted to communicate that: (a) only some but not all of the invoices are unpaid. (b) at least some and maybe all of the invoices are unpaid.

The order of presentation of the forced-choice answers was randomized. Next, participants answered all the remaining questions on a 1-7 Likert scale:

To what extent is the main accountant's utterance trustworthy? $(1=$ not at all trustworthy; 7 = completely trustworthy)

To what extent do you agree with the following statement: 'the main accountant knows how many invoices are unpaid'? $(1=$ completely disagree; $7=$ completely agree)

After answering the question on trust and knowledge, participants were either presented with the information "It turns out that all of the invoices are unpaid" or with 
the information "It turns out that not all of the invoices are unpaid." Next, participants answered the following questions:

To what extent do you agree with the following statement: 'the main accountant's utterance was a lie'? ( $1=$ completely disagree; $7=$ completely agree $)$

To what extent is the main accountant blameworthy, if at all, for uttering 'some of the invoices are unpaid'? $(1=$ not at all blameworthy; $7=$ extremely blameworthy)

How much punishment, if any, does the main accountant deserve for uttering "some of the invoices are unpaid"? $(1=$ no punishment at all; $7=$ severe punishment)

Finally, participants answered a comprehension check question. The survey ended with a demographic questionnaire. ${ }^{10}$

\subsection{Results}

\subsubsection{Ex Ante}

The mean ex ante probability ratings were above 50 points in all three context types: the lowest rating was 68.63 in the neutral context type (cf. Table 2). This result means that there was no risk that participants would later confound in the answers on ex post probability a belief in the speaker's words (that there is a low probability of all objects having the property) with a prior belief that there is very little chance that all objects would have the relevant property.

\subsubsection{Ex Post}

In a paired samples $t$ test, I compared answers on ex ante and ex post probabilities from the same participants (within subjects) for all three contexts groups separately (neutral vs. courtroom without motive vs. courtroom with a motive). There was a significant difference for all three groups, and the effect size of the difference was only somewhat reduced for the courtroom context with a motive. While the assessment of the likelihood that all the objects had the relevant property was around 50 points for the neutral and courtroom scenarios, it rose to around 60 points in the motive scenario. Cf. Table 3.

\subsubsection{Communicated Content}

The majority of participants inferred the implicature because the majority took the utterance as communicating "some but not all" of the invoices are unpaid.

\footnotetext{
10 At the end of the survey, I asked a comprehension check question to ensure that participants understood the context manipulation:

Where did the conversation take place? (a) At the company. (b) In a courtroom.

The order of answer presentations was randomized.
} 
The percentage of participants who chose the two alternative answers to the question on communicated content for different contexts is presented in Table 4 together with a chi-square test depicting the significant difference between the number of participants choosing some but not all versus maybe all (all ps <0.001).

\subsubsection{The Influence of Trust and Knowledge}

Crucially, in line with our hypothesis, in all three context types, participants that judged the protagonist as knowing (answers above the mid-point 4) as well as answering that they did not trust the utterance (answers below the mid-point 4) ascribed highest ex ante and ex post probabilities of all objects having the property (cf. Table 5). The highest scores were in the motive context (cf. Table 5).

Moreover, in line with the prediction, in the "courtroom with motive" context type, participants chose the answer "at least some and maybe all" to the question on communicated content $42 \%$ of the time, which is descriptively higher than the other context types. In a chi-square test, I found no significant difference between the two types of answers. A similar pattern (no significant difference) occurred in the neutral
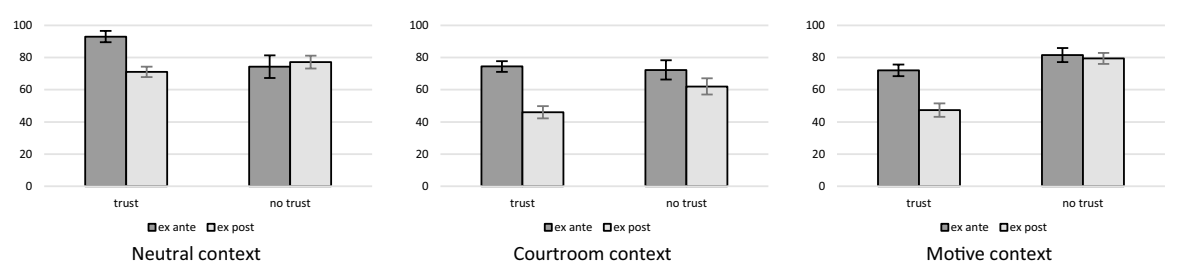

Fig. 1 Mean ratings of ex ante and ex post probability depending on trust judgment and context type. Error bars depict the standard error of the mean

Table 3 Paired samples $t$ test comparing the difference in assessment of the probability of all objects having the relevant property before and after hearing utterance for each of the three context types

\begin{tabular}{lllllll}
\hline Context & Mean ex ante (SD) & Mean ex post (SD) & \multicolumn{5}{l}{ Ex ante versus ex post } \\
\cline { 4 - 7 } & & & $t(d f)$ & $p$ & Cohen's $d$ & $95 \%$ CI \\
\hline Neutral & $68.63(31.83)$ & $54.35(29.77)$ & $4.88(171)$ & $<.001$ & .37 & {$[8.50 ; 20.05]$} \\
Courtroom & $69.69(30.58)$ & $52.75(31.54)$ & $5.44(165)$ & $<.001$ & .42 & {$[10.80 ; 23.09]$} \\
Motive & $76.57(29.06)$ & $63.64(31.89)$ & $4.29(150)$ & $<.001$ & .35 & {$[6.97 ; 18.90]$} \\
\hline
\end{tabular}

$95 \%$ confidence intervals are given for the means

Table 4 Percentage of participants that judged the communicated content as either "some but not all" or "at least some and maybe all" in the three context types as well as chi-square test against chance results

\begin{tabular}{lllll}
\hline & $\begin{array}{l}\text { Some but } \\
\text { not all (\%) }\end{array}$ & Maybe all (\%) & $\chi^{2}(\mathrm{df})$ & $p$ \\
\hline Neutral & 66 & 34 & $16.95(1)$ & $<.001$ \\
Courtroom & 69 & 31 & $24.68(1)$ & $<.001$ \\
Motive & 65 & 35 & $13.41(1)$ & $<.001$ \\
\hline
\end{tabular}


context: inference of intent to mislead (knowledge and low trust ascription) made it less likely that the implicature would be inferred through the choice of the "at least some and maybe all" answer to the question on communicated content (cf. Table 6).

In a one-way ANOVA, I compared the answers on trust and knowledge between the three context types and found an effect of context type on trust and knowledge; cf. Table 7.

Following my predictions, for the knowledge assessment of the protagonist, there was a significant difference between average answers from the neutral and the courtroom context, while no difference occurred between the courtroom and motive contexts (cf. Table 8). Knowledge assessment increased in the courtroom context as compared to the neutral context (cf. Table 9).

In contrast, trust assessment decreased in the courtroom without explicit motive context (cf. Table 8). There was a significant difference between average trust assessment in the neutral and the courtroom without explicit motive contexts. There

Table 5 Paired samples $t$ test comparing the difference in assessment of the probability of all objects having the relevant property before and after hearing the utterance in three context types

\begin{tabular}{lllllllll}
\hline Context & Mean ex ante (SD) & Mean ex post (SD) & \multicolumn{5}{l}{ Ex ante versus ex post } \\
\cline { 5 - 8 } & & & \multicolumn{2}{l}{$t(d f)$} & $p$ & Cohen's $d$ & $95 \%$ CI & $N$ \\
\hline Neutral & $74.29(34.33)$ & $77.08(4.42)$ & $-.36(23)$ & .725 & .07 & {$[-19.03 ; 13.45]$} & 24 \\
Courtroom & $72.28(36.23)$ & $62.03(30.64)$ & $1.58(35)$ & .124 & .26 & {$[-2.95 ; 23.45]$} & 36 \\
Motive & $81.51(29.05)$ & $79.42(23.08)$ & $.40(44)$ & .690 & .06 & {$[-8.40 ; 12.58]$} & 45 \\
\hline
\end{tabular}

This is data restricted to participants who ascribed knowledge over mid-point 4 and trust below midpoint $4.95 \%$ confidence intervals are given for the means

Table 6 Percentage of participants that judged the communicated content as either "some but not all" or "at least some and maybe all" in the three context types as well as chi-square test results comparing the number of answers

\begin{tabular}{llllr}
\hline & Some but not all $(\%)$ & Maybe all $(\%)$ & $\chi^{2}(d f)$ & $p$ \\
\hline Neutral & 62 & 38 & $1.50(1)$ & .221 \\
Courtroom & 69 & 31 & $5.44(1)$ & .020 \\
Motive & 58 & 42 & $1.09(1)$ & .297 \\
\hline
\end{tabular}

This data is restricted to participants who ascribed knowledge over mid-point 4 and trust below midpoint 4

Table 7 One-way ANOVA to compare influence of context on trust and knowledge across context types

\begin{tabular}{lll}
\hline & \multicolumn{2}{l}{ Context influence } \\
\cline { 2 - 3 } & $F(d f)$ & $p$ \\
\hline Trust & $4.20(2)$ & .016 \\
Knowledge & $4.57(2)$ & .011 \\
\hline
\end{tabular}


Table 8 Independent samples $t$ tests comparing average knowledge and trust assessment in between the three context types

\begin{tabular}{|c|c|c|c|c|c|c|c|c|}
\hline & \multicolumn{4}{|l|}{ Trust } & \multicolumn{4}{|l|}{ Knowledge } \\
\hline & $T(d f)$ & $p$ & $d$ & $95 \% \mathrm{CI}$ & $T(d f)$ & $p$ & $d$ & $95 \% \mathrm{CI}$ \\
\hline Neutral versus courtroom & $2.10(270)$ & .037 & .25 & {$[.02 ; .68]$} & $-2.65(270)$ & .008 & .32 & {$[-.77 ;-.11]$} \\
\hline Courtroom versus motive & $1.26(267)$ & .209 & .15 & {$[-.14 ; .62]$} & $.09(267)$ & .926 & .01 & {$[-.29 ; .32]$} \\
\hline
\end{tabular}

$95 \%$ confidence intervals are given for the means

Table 9 Average trust and knowledge assessment in all three contexts; standard deviation from the mean is indicated in brackets

\begin{tabular}{lll}
\hline & Trust $(S D)$ & Knowledge $(S D)$ \\
\hline Neutral & $4.75(1.30)$ & $5.52(1.44)$ \\
Courtroom & $4.40(1.46)$ & $5.96(1.30)$ \\
Motive & $4.16(1.66)$ & $5.95(1.26)$ \\
\hline
\end{tabular}

was no difference between the courtroom without explicit motive and the courtroom with explicit motive contexts (cf. Table 8).

\subsection{Lying}

Next, I analyzed the answers of participants who were presented with the information "It turns out that all of the invoices were unpaid." I restricted the analysis to datasets where the knowledge judgment was above the midpoint 4 on the Likert scale.

As predicted, for all three contexts, participants who judged the communicated content as "at least some and maybe all" judged the protagonist as not lying, while those who judged the communicated content as "some but not all" judged the protagonist as lying; cf. Table 10.

Next, I compared the above answers on the lying question depending on whether the trust judgment was above or below the midpoint 4 . I explored the variation of lying judgments depending on both ascribed communicated content and ascribed trust.

For the neutral context, trust did not affect lying judgments: regardless of whether participants trusted the protagonist, they judged her as lying if they ascribed to her the communicated content "some but not all," while they judged her as not lying if they ascribed to her the content "at least some and maybe all." An identical pattern occurred for the courtroom context (cf. Table 11 and Fig. 2). By contrast, for the context containing a motive, judgments of lies for those who judged the utterance as communicating "some but not all" differed significantly depending on whether they trusted the protagonist. If participants trusted the protagonist, they judged her as not lying, while if they distrusted her, they found she lied. 
Table 10 One sample $t$ test checking difference of lying judgment from mid-point 4 depending on the chosen answer on communicated content

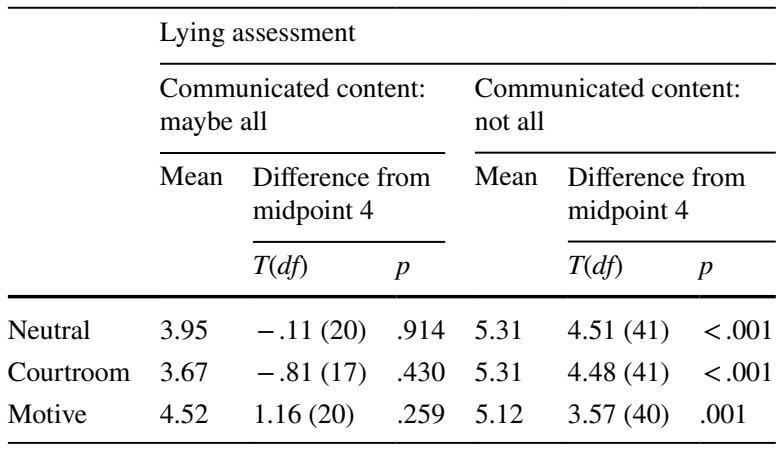

The data is restricted to participants who were presented with the information "It turns out that all of the invoices were unpaid" and assessed the protagonist as knowing how many invoices were unpaid (rating above mid-point 4)

Moreover, even those who judged the utterance as communicating "at least some and maybe all" exhibited a difference in lie assessment depending on the level of trust: the effect size of the difference is medium: .69 (cf. Table 11). In line with the bias suspicion, participants first judged the utterance as communicating that perhaps all objects had the property, and later, when they were presented with the information that all the objects indeed had the property, they judged the protagonist as lying, so they held her responsible for something she did not communicate. This is unfair: responsibility for perjury is responsibility for content that the speaker communicated (or at least was ascribed to be communicating). Otherwise, how can a speaker believe content to be false if she is not communicating it in the first place?

For these participants, the mean lying judgment was 5.18, $\mathrm{SD}=2.27$, though the mean was only borderline significantly different from mid-point 4: $t(8)=2.29$, $p=.056$. Thus, the analyzed participants had a tendency toward holding the protagonist responsible for something they thought she did not communicate. They did not do so if presented with the information that it turned out that not all the objects had the property: $M=2.2, \mathrm{SD}=1.81$; significant difference from mid-point four $t(9)=-3.14, p=.012,95 \%$ CI $[-3.10 ;-.50]$.

\subsubsection{Blame}

Finally, I checked whether the above-described dependence of lying judgments on trust levels was reflected in participants' assessment of blame and punishment. Contrary to predictions, it is not that if one breaks trust, then one is more blameworthy, but rather that the less one is trusted, the more one is blamed for lying, and the more one is trusted, the less one is blamed for lying. For instance, for the motive context, where the effect was strongest, if participants chose the answer on communicated content "some but not all," if they trusted the speaker's words, they rated lies and blame on average as 4.15 and 4.85 respectively. The blame judgment 
Table 11 Independent samples $t$ test comparing mean lying judgments depending on level of trust (yes $=$ above the mid-point 4 vs no $=$ below the midpoint 4 ) and ascribed communicated content for participants who judged the protagonist as knowing how many objects had the property and were presented with the information that it turned out that all the objects had the property in question

\begin{tabular}{|c|c|c|c|c|c|c|c|c|}
\hline & \multicolumn{8}{|c|}{ Influence of trust on lies } \\
\hline & \multicolumn{4}{|c|}{ Communicated content: maybe all } & \multicolumn{4}{|c|}{ Communicated content: not all } \\
\hline & $T(d f)$ & $p$ & $d$ & $95 \% \mathrm{CI}$ & $T(d f)$ & $p$ & $d$ & $95 \% \mathrm{CI}$ \\
\hline Neutral & $-.07(19)$ & .947 & .03 & {$[-2.13 ; 1.99]$} & $-.29(40)$ & .770 & .10 & {$[-1.55 ; 1.15]$} \\
\hline Courtroom & $0(16)$ & 1.00 & 0 & {$[-1.91 ; 1.91]$} & $-.91(40)$ & .369 & .30 & {$[-1.79 ; .68]$} \\
\hline Motive & $-1.59(19)$ & .128 & .69 & {$[.87 ;-3.20]$} & $-3.39(39)$ & .002 & 1.06 & {$[-3.03 ;-.76]$} \\
\hline
\end{tabular}

I checked each context type separately. 95\% confidence intervals are given for the means

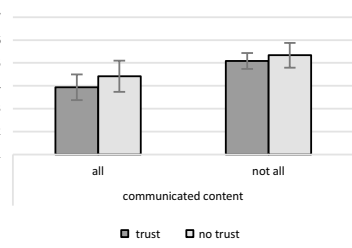

Lying judgment in neutral context

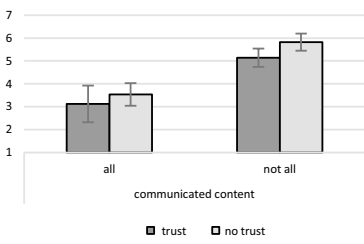

Lying judgment in courtroom context

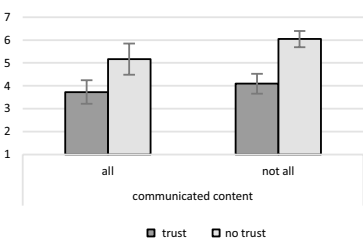

Lying judgment in motive context

Fig. 2 Mean lying judgments depending on level of trust and ascribed communicated content for participants who judged the protagonist as knowing how many objects had the property and were presented with the information that it turned out that all the objects had the property in question. I compare each context type separately. Error bars represent the standard error of the mean

was not significantly different from the midpoint $4: t(10)=2.04, p=.068,95 \% \mathrm{CI}$ $[-.07 ; 1.71]$.

By contrast, when they did not trust the speaker's words, they rated lies and blame as 6.05 and 6.38, respectively. The blame judgment was significantly different from the mid-point 4: $t(8)=10.09, p<0.001$, 95\% CI [1.89; 3.00] (cf. Table 12).

In the motive context, participants who judged the protagonist as communicating "some and maybe all", as well as distrusted the speaker, also judged the protagonist as lying and blameworthy. In line with our hypothesis, I suggest participants did so because they blamed the protagonist for trying to mislead the audience with the utterance: participants ascribed the protagonist an intent to mislead.

These findings indicate that assessments of lying are at least as much moral judgments as epistemic ones. Moreover, this goes against both the theory of lies and the theoretical construction of the institution of perjury. This is because, theoretically speaking, intention to mislead is taken as less blameworthy than intention to deceive. Intention to mislead is not an intention to lie (cf. for instance 
[65]). Moreover, the only thing that counts for perjury ascriptions according to the SC is whether the speaker believed her answer to be true. Consequently, this apparent influence of moral judgment on epistemic judgment could be considered a bias.

\subsubsection{Punishment}

Contrary to predictions, for participants that judged the protagonist as knowledgeable and were presented with the information that all objects had the property, punishment levels were not pronounced, regardless of trust and communicated content; they never rose significantly above the mid-point 4: participants tended to be unwilling to punish the protagonist for her words $M=4.08, \mathrm{SD}=1.81, t(208)=.65$, $p=.515$ (cf. Table 12).

\subsection{Discussion}

On average, for all three tested context types (neutral vs. courtroom with no motive to lie vs. courtroom with a motive to lie), participants inferred the implicature "some but not all" because they answered that the protagonist's utterance communicated that "some but not all" of the objects had the relevant property. Thus, the SC's worry that participants would not make a sharp distinction between casual and courtroom contexts is well founded. Moreover, there was a significant difference between their judgments of probability of all objects having the relevant property before and after being presented with the utterance; participants' beliefs on what was communicated with the utterance and on the state of the world were congruent. This means that on average, participants believed in the speaker's words and inferred that not all the objects had the property in question.

By contrast, this pattern reversed when the analysis was restricted to participants that judged the protagonist as knowing how many objects had the property (judgment above mid-point 4) and indicated that the protagonist's words could not be trusted (judgment below mid-point 4). These participants judged the probability of all objects having the property before and after hearing the utterance as similari.e. they did not update their initial belief on the basis of the speaker's utterance. Moreover, the highest number of such participants was in the motive context where the level of trust was lowest. Just as Marmor suggested, these participants were also the most prone to judge the protagonist's utterance as communicating "At least some and maybe all of the objects have the property," which I take as a lack of inference of the scalar implicature of "some" (a chi-square test revealed no significant difference between the number of answers "some but not all" and "at least some and maybe all" in the question on communicated content). Thus, the results provide some support for Marmor's interpretation of the Bronston's case.

As predicted, in the two courtroom context types (courtroom and courtroom with a motive to lie), there were higher knowledge ascriptions and lower trust ascriptions than in the third neutral context type. 


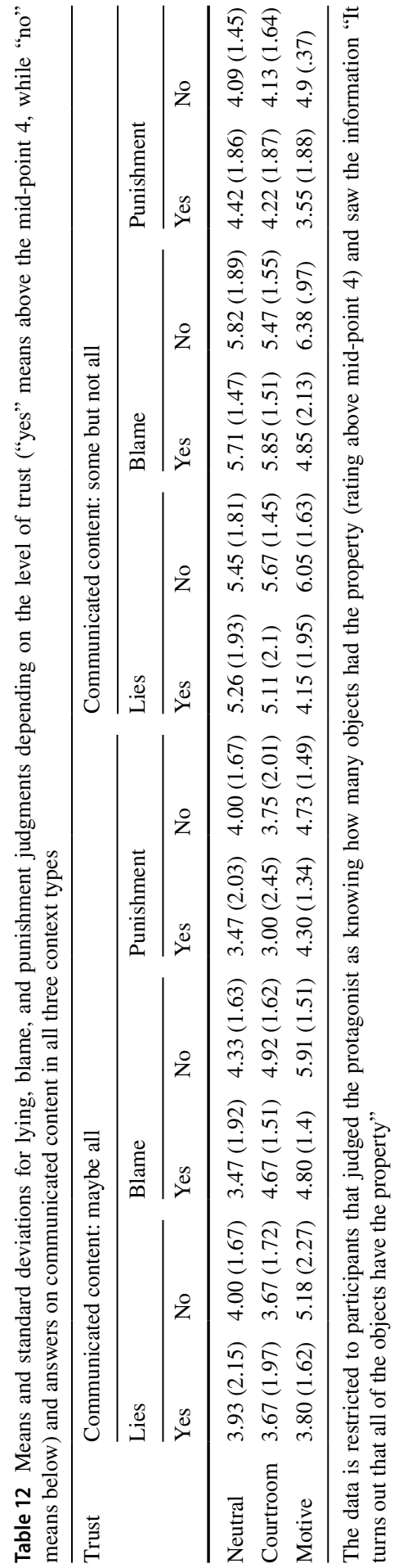


Among those participants that judged the protagonist as knowing how many invoices were unpaid (ratings above the mid-point 4) and were presented with the information that it turned out that all the objects had the relevant property, for all three context types, participants who judged the communicated content as "at least some and maybe all" judged the protagonist as not lying, while those who judged the communicated content as "some but not all" judged the protagonist as lying. Thus, just as the Supreme Court in the Bronston ruling suggested, there is a robust folk intuition that a false implicature in the courtroom is a lie.

However, I observe a worrying influence of trust levels on lie assessment in the motive context: among those participants that judged the protagonist as knowing, judged the utterance's communicated content as "some but not all," and were presented with the information "It turns out that all of the objects have the relevant property," those who trusted the protagonist judged her as truthful, while those who did not trust her judged her as lying. The same pattern was reflected in blame assessment. Surprisingly, it is not that if one breaks trust then one is more blameworthy, but rather the less one is trusted, the more one is blamed for lying, and the more one is trusted, the less one is blamed for lying.

Moreover, I observe another worrying influence of trust levels on lie assessment in the motive context: participants that judged the protagonist as knowledgeable, distrustful, and communicating "At least some and maybe all objects have the property" and that were presented with the information that it turned out that all the objects had the property judged the protagonist as lying (borderline significance from mid-point 4). In other words, they held her responsible for content she did not communicate. This was reflected in blame judgments: participants most probably blamed the protagonist for trying to fool them; they ascribed to the protagonist an intent to mislead.

Contrary to predictions, participants were unwilling to punish the protagonist for her words in all conditions.

\section{General Discussion}

In the case of the utterance containing the word "some," that typically generates scalar implicature ('not all'), there is a robust folk intuition in the present study across all tested contexts that a false implicature is a lie. This goes against previous experimental findings (cf. [17, 83, 84]). Perhaps the present results are a consequence of not asking a separate question on misleading: if misleading and lying were differentiated in the experimental setting, perhaps participants would judge the utterance as misleading rather than a lie. This remains an avenue for future investigation.

Most participants judged the protagonist as communicating that not all the objects had the property. When presented with the information that it turned out that all the objects had the property, participants judged the protagonist as having uttered a lie in all three tested context types. Thus, the SC's first major worry that participants do not make a sharp distinction between casual and courtroom contexts is well founded.

The second main worry of the SC, that participants will behave inconsistently in the presence of a motive to lie ascribed to the speaker due to low trust levels, is 
also well founded. When the dataset is restricted to participants that do not trust the speaker's words, in the motive context, roughly half of participants behave as Marmor predicted: that is, participants refrain from implicature inference. The remaining participants behave as Bianchi predicted. They infer the implicature yet disbelieve the speaker.

Moreover, there are two main patterns of lie ascriptions that are inconsistent in the motive context. The first one concerns Marmor's and the SC's worry: participants judge the utterance as communicating that maybe all objects have the property. Next, when presented with the information that it turns out that indeed all objects have the property, they judge the protagonist as lying. This means that they hold the protagonist responsible for content she did not communicate. These participants also judge the protagonist as knowledgeable and ascribe a low trust level toward the protagonist's words. Finally, these same participants ascribe a high blame level. For this reason, I suppose that they ascribe to the protagonist an intent to mislead (cf. Fig. 3).

Our interpretation of this result should be treated with caution and requires further investigation, yet I suppose that these participants treat the speaker's utterance as a trap that is supposed to fool them into thinking that not all the objects have the property, even though they do not fall into this trap, and thus perhaps the utterance should be treated as at best misleading rather than an outright lie. Since the mens rea for intention is constituted of knowledge plus desire (the so-called cognitive and volitional elements, cf. for instance [59], I take the distrust ascription as a substitute for an ascription of a desire to mislead. If knowledge is also ascribed to the protagonist, then this together with the distrust ascription generates an ascription of an intent to mislead. The ascription of intent to mislead in turn influences the lying judgment, though, as the SC noted, it should not (Fig. 4).

Moreover, what if the speaker is just not sure of her words or has not really considered what her utterance implicates, as suggested by the SC (cf. Section 6.9, [10]?

Our results suggest that the SC is right that a distrusted witness might later be held responsible for implicatures that she did not genuinely intend or think of. After all, not every witness under oath has an intent to mislead, while many are stressed by the rather unusual setting of a witness cross-examination [3]. This is especially pressing given the maxim that a motive to act should be irrelevant to responsibility if one is not certain that the defendant acted upon the motive (cf. for instance [53, 59]).

The second worrying inconsistency in folk intuitions about perjury also concerns the motive context. This worry is even more serious because it concerns the majority of participants in the experiment. Namely, participants that judged the utterance as communicating that not all the objects had the property, after being presented with the information that it turned out that all the objects had the property, judged the utterance as a lie merely on average. This is because if these participants are split into two groups-those who trusted and those who distrusted the speaker's utterance-only those who distrusted judged the utterance as a lie. A trusted speaker is not judged as a liar even though her utterance communicates a content contrary to the state of the world. This is worrying because trust is an emotional variable that is easily manipulable [15, 30, 38, 42]. Empirical research suggests that an initial trust assessment upon first encounter is later extremely 


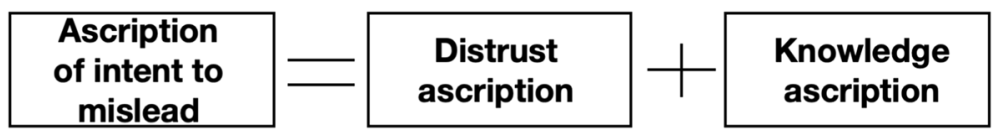

Fig. 3 Model of ascriptions of intent to mislead

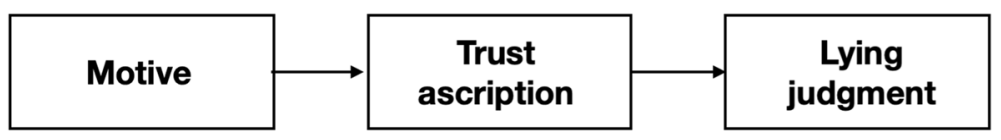

Fig. 4 Influence of motive on trust and lying ascriptions

difficult to alter [88]. Further research suggests that the speaker's face, understood as the speaker's political views and attributed social role, as well as trust, can influence linguistic judgments $[9,61,73,74]$. In addition to all this, experimental studies confirm that the speaker's presumed competence or impairment also influences utterance interpretation in a systematic way [29].

As previously stated, surprising pattern also concerns blame ascriptions: it is not that if one breaks trust then one is more blameworthy, but rather the less one is trusted, the more one is blamed for lying, and the more one is trusted, the less one is blamed for lying (Fig. 5).

Finally, it should be emphasized that in adversarial systems such as the American system, there is more leniency toward misleading statements because during witness cross-examination, it is the duty of the questioning lawyer to precisely inquire about the crucial elements of the case: "Precise questioning is imperative as a predicate for the offense of perjury" [10].

This, however, is less present in Continental systems, where the influence of trust might therefore be even more worrying. ${ }^{11}$ In other words, since in continental legal systems there is no witness cross-examination practice, perhaps the witness has more of a duty to answer the question precisely, while still having no obligation to reveal extra information. If this is the case, then, based on our experimental results, a trusted witness might be treated more leniently than an untrusted one, even if both communicate the same content. On the other hand, however, even in common law systems, the witness has a responsibility to answer questions:

'(...) a witness is required to give relevant and relatively complete responses, and we should be able to interpret the answer accordingly. Were it not so, the entire questioning process would collapse. On the other hand, the nature of the

\footnotetext{
11 As the SC notes in Bronston: "Montesquieu took as his starting point the French tradition of capital punishment for perjury and the relatively mild English punishment of the pillory. He thought the disparity between the punishments could be explained because the French did not permit the accused to present his own witnesses, while in England 'they admit of witnesses on both sides, and the affair is discussed in some measure between them; consequently false witness is there less dangerous, the accused having a remedy against the false witnesses, which he has not in France.' Montesquieu, The Spirit of the Laws, quoted in Study of Perjury, supra [p. 253., 10]
} 


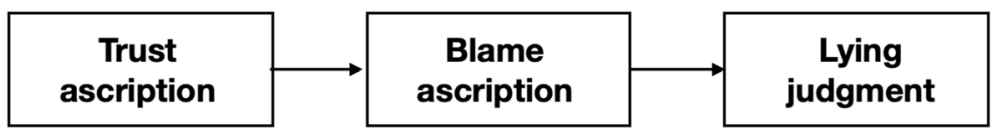

Fig. 5 Influence of trust on blame and lying ascriptions

adversarial process suggests that it is the questioning lawyer's job to ensure that responses comply with these requirements. But who do we blame when, as seems to have happened in Bronston, the witness intentionally gives an unresponsive answer to create a false impression of responsiveness? Do we let Bronston's creditors go uncompensated because their lawyer's trial skills were not sufficiently honed, or do we prosecute the witness for perjury to discourage deceitful conduct?

We believe that the most practical solution is to require the lawyer to clarify unresponsive answers, as the Supreme Court suggested, but only when it is reasonably evident to the lawyer that the answer may not be responsive. If we interpret the question in Bronston as asking about personal bank accounts in Switzerland, it should have been evident to the examining lawyer that Bronston's reply about company bank accounts was not responsive to the question. While in ordinary conversation this would lead the hearer to infer that Bronston had no personal accounts in Switzerland, this was a legal setting, and therefore the lawyer should have probed further.' [67]

\section{Conclusion}

In the present study folk intuitions about perjury appear to be fairly robust: in the tested case false implicatures are judged as lies, though lies that do not deserve punishment. However, the Supreme Court's worry, expressed in the Bronston case, that folk intuitions about perjury do not differ between casual and courtroom contexts, even though for various reasons they should, is also well founded. In the courtroom, it is the duty of the cross-examining lawyer to precisely inquire about central matters, while there is no such duty in casual contexts.

Moreover, a more careful analysis of the data reveals that participants who distrust the speaker's utterance tend to hold the speaker responsible for content she did not communicate. They do so because they retrospectively ascribe to the speaker an intent to mislead them. This, however, is an irrelevant (non-material) element of the offense of perjury.

We also find a second worrying influence of trust on lying ascriptions in the courtroom: a trusted speaker is exculpated from lying even if the implication drawn from her words turns out to be false. By contrast, a distrusted speaker is judged in the exact same circumstances as a liar.

Since trust is an emotional variable, which is easy to manipulate with various elements, including a putative motive, we should follow the SC's warning and be extremely cautious with trust toward jury-issued perjury judgments. 
Electronic supplementary material The online version of this article (https://doi.org/10.1007/s1119 6-021-09818-w) contains supplementary material, which is available to authorized users.

Acknowledgements This research was funded by the National Science Centre, Poland, Preludium Grant No. 2015/19/N/HS5/00029. I would like to thank Anna Drożdżowicz, Laurence Horn, Katarzyna KijaniaPlacek, Markus Kneer, Francesca Poggi, Barbara Spellman, Maciej Próchnicki and Alex Wiegmann for comments on drafts.

Open Access This article is licensed under a Creative Commons Attribution 4.0 International License, which permits use, sharing, adaptation, distribution and reproduction in any medium or format, as long as you give appropriate credit to the original author(s) and the source, provide a link to the Creative Commons licence, and indicate if changes were made. The images or other third party material in this article are included in the article's Creative Commons licence, unless indicated otherwise in a credit line to the material. If material is not included in the article's Creative Commons licence and your intended use is not permitted by statutory regulation or exceeds the permitted use, you will need to obtain permission directly from the copyright holder. To view a copy of this licence, visit http://creativecommons.org/licen ses/by/4.0/.

\section{References}

1. Adler, J. 1997. Lying, deceiving, or falsely implicating. Journal of Philosophy 94: 435-452.

2. Alicke, M.D. 2000. Culpable control and the psychology of blame. Psychological Bulletin 126 (4): 556-574. https://doi.org/10.1037/0033-2909.126.4.556.

3. Angermuller, J. ed. 2014. Introduction: Poststructuralism and enunciative pragmatics. In Poststructuralist discourse analysis. Postdisciplinary studies in discourse. London: Palgrave Macmillan. https://doi.org/10.1057/9781137442475_1

4. Atlas, J.D., and S.C. Levinson. 1981. It clefts, informativeness and logical form: Radical pragmatis (Revised Standard Version). In Radical pragmatics, ed. P. Cole, 1-62. London: Academic Press.

5. Badar, M. E. 2013. The concept of mens rea in international criminal law: The case for a unified approach, 540. Hart Publishing.

6. Baron, J., and J.C. Hershey. 1988. Outcome bias in decision evaluation. Journal of Personality and Social Psychology 54 (4): 569-579. https://doi.org/10.1037/0022-3514.54.4.569.

7. Benillouche, M. 2005. La subjectivisation de l'element moral de l'infraction, plaidoyer pour une nouvelle theorie de la culpabilite. London: RSC.

8. Bianchi, C. 2016. What did you (legally) say? Cooperative and strategic interactions. In Pragmatics and law, ed. A. Capone and F. Poggi, 185-199. Berlin: Springer. https://doi.org/10.1007/978-3-31930385-7_9.

9. Bonnefon, J.-F., A. Feeney, and G. Villejoubert. 2009. When some is actually all: Scalar inferences in face-threatening contexts. Cognition 112 (2): 249-258. https://doi.org/10.1016/j.cogni tion.2009.05.005.

10. Bronston v. United States, 409 U.S. 352. 1973. http://cdn.loc.gov/service/11/usrep/usrep409/usrep 409352/usrep409352.pdf.

11. Chierchia, Genaro. 2004. Scalar implicatures, polarity phenomena and the syntax/pragmatics interface. In Structures and beyond: The cartography of syntactic structures, ed. A. Bettelli, 39-103. Oxford: Oxford University Press.

12. Chierchia, Gennaro. 2006. Broaden your views: Implicatures of domain widening and the "logicality" of language. Linguistic Inquiry 37 (4): 535-590. https://doi.org/10.1162/ling.2006.37.4.535.

13. Chierchia, Genaro, B. Spector, and D. Fox. 2011. The grammatical view of scalar implicatures and the relationship between semantics and pragmatics. In Handbook on semantics, ed. P. Portner, C. Maienborn, and K. von Heusinger. Berlin: De Gruyter.

14. Chisholm, R.M., and T.D. Feehan. 1977. The intent to deceive. The Journal of Philosophy 74 (3): 143. https://doi.org/10.2307/2025605.

15. Cramer, R.J., S.L. Brodsky, and J. DeCoster. 2009. Expert witness confidence and juror personality: Their impact on credibility and persuasion in the courtroom. The Journal of the American Academy of Psychiatry and the Law 37 (1): 63-74. 
16. Cushman, F., A. Dreber, Y. Wang, and J. Costa. 2009. Accidental outcomes guide punishment in a "trembling hand" game. PLoS ONE 4 (8): e6699. https://doi.org/10.1371/journal.pone.0006699.

17. Doran, R., G.L. Ward, Y. McNabb, and R.E. Baker. 2012. A novel paradigm for distinguishing between what is said and what is implicated. Language 88: 124-154.

18. Dowd Maureen. 1998. N. Y. Times op-ed "the wizard of is".

19. Dynel, M. 2011. A web of deceit: A neo-Gricean view on types of verbal deception. International Review of Pragmatics 3 (2): 139-167. https://doi.org/10.1163/187731011X597497.

20. Elliott, C. 2001. French criminal law. Uffculme, Cullompton, Devon: Willan Pub.

21. Fallis, D. 2009. What is lying? Journal of Philosophy 106 (1): 29-56. https://doi.org/10.5840/jphil 200910612.

22. Fox, D. 2007. Free choice and the theory of scalar implicatures. In Presupposition and implicature in compositional semantics, ed. W.U. Sauerland and P. Stateva, 71-120. London: Palgrave Macmillan. https://doi.org/10.1057/9780230210752_4.

23. Franke, M. 2010. Semantic meaning and pragmatic inference in non-cooperative conversation. In Interfaces: Explorations in logic, language and computation, ed. T. Icard and R. Muskens, 13-24. Berlin, Heidelberg: Springer. https://doi.org/10.1007/978-3-642-14729-6_2.

24. Geis, Michael L., and Arnold M. Zwicky. 1971. On invited inferences. Linguistic lnquiry. 2: 561-566.

25. Geurts, B. 2010. Quantity implicatures. Cambridge: Cambridge University Press.

26. Goodman, N.D., and A. Stuhlmüller. 2013. Knowledge and implicature: Modeling language understanding as social cognition. Topics in Cognitive Science 5 (1): 173-184. https://doi.org/10.1111/ tops. 12007 .

27. Grice, H.P. 1989. Studies in the way of words. Cambridge: Harvard University Press.

28. Grice, P. 1975. Logic and conversation. In Syntax and semantics, ed. P. Cole and J.L. Morgan, 41-58. London: Academic Press.

29. Grodner, D., and J.C. Sedivy. 2011. The effect of speaker-specific information on pragmatic inferences. In The processing and acquisition of reference, ed. E.A. Gibson and N.J. Pearlmutter, 239272. London: The MIT Press. https://doi.org/10.7551/mitpress/9780262015127.003.0010.

30. Herz, H., A. Schmutzler, and A. Volk. 2019. Cooperation and mistrust in relational contracts. Journal of Economic Behavior and Organization 166: 366-380. https://doi.org/10.1016/j. jebo.2019.07.007.

31. Horn, Laurence R. 1972. On the semantic properties of logical operators in English. University of California doctoral dissertation.

32. Horn, Laurence R. 2000. From if to iff: Conditional perfection as pragmatic strengthening. Journal of Pragmatics 32 (3): 289-326. https://doi.org/10.1016/S0378-2166(99)00053-3.

33. Horn, Laurence R. 2006. Implicature. In The handbook of pragmatics, ed. Laurence R. Horn and Gregory Ward. London: Blackwell. https://doi.org/10.1002/9780470756959

34. Horn, Laurence R. 2017. Telling it slant: Toward a taxonomy of deception. In The pragmatic turn in law, ed. J. Giltrow and D. Stein. Berlin: De Gruyter. https://doi.org/10.1515/9781501504723-002.

35. Horn, Laurence R. 2018. Perjury, puffery, and the presidency: Two ways to not (quite) lie. Pragmatics of legal discourse workshop, AMPRA 4, Albany.

36. Horn, Lawrence R. 1984. Toward a new taxonomy for pragmatic inference: Q-based and R-based implicature. In Round table on languages and linguistics and Georgetown University Meaning, form and use in context: Linguistic applications, ed. D. Schiffrin, 11-42. Georgetown: Georgetown University Press.

37. Kneer, M., and E. Machery. 2019. No luck for moral luck. Cognition 182: 331-348. https://doi. org/10.1016/j.cognition.2018.09.003.

38. Krueger, F., and A. Meyer-Lindenberg. 2019. Toward a model of interpersonal trust drawn from neuroscience, psychology, and economics. Trends in Neurosciences 42 (2): 92-101. https://doi. org/10.1016/j.tins.2018.10.004.

39. Lagnado, D.A., and S. Channon. 2008. Judgments of cause and blame: The effects of intentionality and foreseeability. Cognition 108: 754-770.

40. Levinson, S.C. 1983. Pragmatics (nineteenth printing, 2008). Cambridge: Cambridge University Press.

41. Levinson, S.C. 2000. Presumptive meanings: The theory of generalized conversational implicature. London: MIT Press.

42. Lewis, J.D., and A. Weigert. 1985. Trust as a social reality. Social Forces 63 (4): 967. https://doi. org/10.2307/2578601. 
43. Macagno, F., D. Walton, and G. Sartor. 2017. Pragmatic maxims and presumptions in legal interpretation. Law and Philosophy. https://doi.org/10.1007/s10982-017-9306-4.

44. Malle, B.F., S. Guglielmo, and A.E. Monroe. 2014. A theory of blame. Psychological Inquiry 25: 147-186.

45. Margoni, Francesco, and Luca Surian. 2020. Judging accidental harm: Due care and foreseeability of side effects. Current Psychology.

46. Marmor, A. 2008. The pragmatics of legal language. Ratio Juris 21 (4): 423-452. https://doi.org/10. 1111/j.1467-9337.2008.00400.x.

47. Marmor, A. 2014. The language of law, 1st ed. Oxford: Oxford University Press.

48. Meibauer, J. 2005. Lying and falsely implicating. Journal of Pragmatics 37 (9): 1373-1399. https:// doi.org/10.1016/j.pragma.2004.12.007.

49. Meibauer, J. 2014. Lying at the semantics-pragmatics interface. Berlin: De Gruyter.

50. Michaelson, E. 2016. The lying test: The lying test. Mind and Language 31 (4): 470-499. https:// doi.org/10.1111/mila.12115.

51. Monroe, A.E., and B.F. Malle. 2017. Two paths to blame: Intentionality directs moral information processing along two distinct tracks. Journal of Experimental Psychology: General 146: 123-133.

52. Nadelhoffer, T. 2006. Bad acts, blameworthy agents, and intentional actions: Some problems for juror impartiality. Philosophical Explorations 9 (2): 203-219. https://doi.org/10.1080/1386979060 0641905.

53. Nadler, J., and M. Hunter-Morris. 2011. Moral character, motive and the psychology of blame. Faculty working papers. https://scholarlycommons.law.northwestern.edu/facultyworkingpapers/14.

54. Noveck, I.A. 2001. When children are more logical than adults: Experimental investigations of scalar implicature. Cognition 78 (2): 165-188. https://doi.org/10.1016/S0010-0277(00)00114-1.

55. Pinker, S., M.A. Nowak, and J.J. Lee. 2008. The logic of indirect speech. Proceedings of the National Academy of Sciences 105 (3): 833-838. https://doi.org/10.1073/pnas.0707192105.

56. Poggi, F. 2011. Law and conversational implicatures. International Journal for the Semiotics of Law-Revue Internationale de Sémiotique Juridique 24 (1): 21-40. https://doi.org/10.1007/s1119 6-010-9201-x.

57. Pradel, J. 2019. Droit Penal general. Cujas.

58. Reins, L.M., and A. Wiegmann. 2020. Is Lying Bound to Commitment? Empirically Investigating Deceptive Presuppositions, Implicatures, and Actions. https://doi.org/10.31234/osf.io/vb67q.

59. Rosenberg, M. 2008. The continued relevance of the irrelevance-of-motive maxim. Duke Law Journal 57 (4): 1144-1177.

60. Russell, B. 2006. Against grammatical computation of scalar implicatures. Journal of Semantics 23 (4): 361-382. https://doi.org/10.1093/jos/ffl008.

61. Sanderson, L. 1995. Linguistic contradiction: Power and politeness in courtroom discourse. Canadian Journal for Studies in Discourse and Writing/Rédactologie 12 (2): 24. https://doi.org/10.31468 /cjsdwr.397.

62. Sarin, A., Ho, M. K., Martin, J., and F. A. Cushman. 2020. Punishment is organized around principles of communicative inference. PsyArXiv. https://doi.org/https://doi.org/10.31234/osf.io/2cyf7.

63. Sauerland, U. 2004. Scalar implicatures in complex sentences. Linguistics and Philosophy 27 (3): 367-391. https://doi.org/10.1023/B:LING.0000023378.71748.db.

64. Sauerland, U. 2012. The computation of scalar implicatures: Pragmatic, lexical or grammatical? Language and Linguistics Compass 6 (1): 36-49. https://doi.org/10.1002/lnc3.321.

65. Saul, J.M. 2012. Lying, misleading, and what is said: An exploration in philosophy of language and in ethics. Oxford: Oxford University Press. https://doi.org/10.1093/acprof:oso/9780199603 688.001.0001.

66. Skoczeń, I. 2019. Implicatures within legal language. Berlin: Springer.

67. Solan, L., and P. Tiersma. 2005. Speaking of crime: The language of criminal justice. Chicago: University of Chicago Press.

68. Solan, L.M. 2018. Lies, deceit, and bullshit in law. Duquesne Law Review 56: 73-104.

69. Solan, L. 2021. Linguistic evidentials and the law of hearsay. In Philosophical foundations of evidence law, eds. Christian Dahlman, Alex Stein \& Giovanni Tuzet. Oxford University Press

70. Spector, B. 2003. Scalar implicatures: Exhaustivity and Gricean reasoning. In B. ten Caten (Ed.), Proceedings of the eighth ESSLLI student session. 277-288.

71. Sperber, D. 1994. Understanding verbal understanding. In What is intelligence?, ed. J. Khalifa, 179198. Cambridge: Cambridge University Press. 
72. Sperber, D., and D. Wilson. 2006. Relevance theory. In The handbook of pragmatics, ed. Laurence R. Horn and G.L. Ward. London: Blackwell.

73. Terkourafi, M., B. Weissman, and J. Roy. 2020. Different scalar terms are affected by face differently. International Review of Pragmatics 12 (1): 1-43. https://doi.org/10.1163/18773109-01201 103.

74. Tiersma, Peter. 2003. Did Clinton lie? Defining "sexual relations". Chi.-Kent L. Rev. 79: 927.

75. Tiersma, P. 2003. Did clinton lie? Defining "sexual relations". 79 Chicago-Kentucky Law Review, 927. http://papers.ssrn.com/sol3/papers.cfm?abstract_id $=470645$.

76. Tiersma, P. 2005. The language of perjury (focusing on the Clinton impeachment). http://www. languageandlaw.org/PERJURY.HTM.

77. Turri, A., and J. Turri. 2015. The truth about lying. Cognition 138: 161-168.

78. Tuzet, G. 2021. The Pragmatics of Evidence Discourse. In Philosophical Foundations of Evidence Law (Christian Dahlman, ed. Alex Stein, and Giovanni Tuzet. Oxford University Press.

79. United Kingdom Perjury Act, Perjury § 1A. 1975. http://www.legislation.gov.uk/ukpga/Geo5/1-2/6/ section/1A.

80. United Kingdom Perjury Statute, Perjury § 1. 1911. http://www.legislation.gov.uk/ukpga/Geo5/12/6/section/1/enacted.

81. United States Code, Perjury § 1621. 1994. http://www.law.cornell.edu/uscode/text/18/1621.

82. Van der Auwera, J. 1997. Pragmatics in the last quarter century: The case of conditional perfection. Journal of Pragmatics 27: 261-274.

83. Van Tiel, B., E. Van Miltenburg, N. Zevakhina, and B. Geurts. 2016. Scalar Diversity. Journal of Semantics. 33 (1): 137-175. https://doi.org/10.1093/jos/ffu017.

84. Weissman, B., and M. Terkourafi. 2018. Are false implicatures lies? An empirical investigation. Mind and Language. https://doi.org/10.1111/mila.12212.

85. Wiegmann, A., J. Samland, and M.R. Waldmann. 2016. Lying despite telling the truth. Cognition 150: 37-42. https://doi.org/10.1016/j.cognition.2016.01.017.

86. Wiegmann, A., J. Meibauer, and P. Willemsen. ms. Lying, deceptive implicatures and commitment.

87. Willemsen, P., and A. Wiegmann. 2017. How the truth can make a great lie: An empirical investigation of the folk concept of lying by falsely implicating. In Conference: 39th annual meeting of the cognitive science society. https://mindmodeling.org/cogsci2017/papers/0663/paper0663.pdf.

88. Xiao, S., and I. Benbasat. 2003. The formation of trust and distrust in recommendation agents in repeated interactions: A process-tracing analysis. In Proceedings of the 5th international conference on electronic commerce-ICEC '03, 287-293. https://doi.org/10.1145/948005.948043.

Publisher's Note Springer Nature remains neutral with regard to jurisdictional claims in published maps and institutional affiliations. 